\title{
Financial Sector Liberalization and Financial Instability: Case of Selected Southern African Development Community Member Countries
}

\author{
Nolungelo Cele, Kapingura FM \\ University of Fort Hare, East London, South Africa \\ FKapingura@ufh.ac.za
}

\begin{abstract}
The importance of financial liberalization is well documented in the literature. However, there has been an emergency of studies, which indicate that this can be another channel through which financial instability is generated in the domestic economy. Utilising data from four SADC countries, the empirical findings show that financial reforms are positively related to financial instability in almost all the specifications. The empirical results further revealed that financial instability intensifies in the face of a financial crisis. The result suggests that financial liberalization can therefore be another source of financial instability in the region. The empirical results imply that though policymakers should liberalise the financial system, policies aimed at maintaining financial stability should also be promoted.
\end{abstract}

\section{Keywords: Financial liberalization, financial instability, Southern African Development Community}

\section{Background of the Study}

The past decade witnessed, several developing countries liberalizing their financial systems with the aim of increasing the scope of the financial sector, and enhancing its role of mobilising and allocating financial resources to productive sectors of the economy (Enowbi and Mlambo, 2012). According to Patnaik (2011) financial liberalization was introduced in developing countries in the 1980s with the aim of giving financial markets a greater role in the development of countries and not just relies on the state. Patnaik (2011) further noted that bringing in financial liberalization was also a response to a number of issues relating to finance in developing countries. These issues included inefficiencies in the financial system, which was stifling the financial sector. McKinnon (1973) and Shaw (1973) defined financial liberalization as "establishing higher interest rates that balance the demand for and the supply of savings". When a country has higher interest rates, this would eventually lead to increased savings and financial intermediation as well as enhance the efficiency of using savings in the economy. This will eventually translate into improved economic growth. However, Magud, Reinhart and Vesperoni (2012) indicate that even though financial liberalization succeeded in easing financial repression, its impact on growth and investment has not been convincing.

At the same time, there are studies such as Demirguc- Kunt and Levine (2008) and Enowbi and Mlambo (2012) which highlight that financial sector liberalization may create financial sector instability and crisis. The financial crisis could manifest itself in the form of bank failures, intense asset price volatility or a collapse in market liquidity. This has the potential of disrupting the payment and settlement process with dire effects as it can be transmitted to the real sector through its linkages with the financial sector. This is also supported by Kaminsky and Schmukler (2003) and Lorenzo (2008). Ikhide and Alawode (2002) also document a number of problems, which many of the African countries went through after liberalizing their financial systems. These challenges include sharp increases in interest rates, bankruptcies of financial institutions and high levels of inflation. Liberalization also resulted in increased capital inflows, which allowed rapid growth in credit to public and private institutions, which were regarded as weak at the time. Demirgüç-Kunt and Levine (2008) also highlight how the quality of lending in general deteriorated in many of the countries, which implemented liberalization.

The SADC 2012 report on financial sector development points out that through the development of the protocol on trade, the region is implementing plans, which are aimed at increasing economic liberalization within the Southern Africa Development Community. The protocol is in line with the SADC vision of a regional integration, which is supported by member states as it is viewed as another way through which the region may have a strong economy as well as increasing international investment. Although much has been put forward to support financial sector liberalization, it becomes important to also examine if it can be another source of financial sector instability in the region given the mixed results in the academic discourse. The paper is organised as follows: following the introduction, section two discuss the available literature, section 
three presents the model utilised in the study with section four and five presenting the discussion of results and conclusions. The study is based on the De Meza and Webb (1987) model, which explains how financial liberalization may result in financial instability. According to the model, financial instability is defined as a decrease in the ability to repay bank loans.

\section{Literature Review and Theoretical Framework}

Financial liberalization is assumed to result in an increase in capital flows which is usually followed by a credit boom. When there is a credit boom, the probability of over-borrowing is high. This is supported by Kaminsky and Schmukler (2003) who argued that the probability of crashes in emerging markets is large in the event that the capital account is open. The model assumes that entrepreneurs borrow money from banks to start up projects. Due to financial liberalization there will be an increase in loanable funds due to an increase in capital flows. This will therefore intensify bank competition as the banks scramble for customers, which may result in a decline in franchise value of banks. In a bid to cope up with the competition, banks may respond by accepting risk exposures which are beyond the usual standards so as to increase profits. Bezemer, et al. (2015) highlights that some of the strategies which banks can engage in include economising on screening and monitoring efforts. Banks may also gamble on their loan allocation decisions. This is in line with Dell'Arricia and Marquez (2006) who argue that in a liberalised financial system, banks may relax their screening efforts, which may increase the risk of the funded projects failing. Lorenzeni (2008) also suggests that competitive financial contracts may result in excessive borrowing ex-ante and excessive volatility expost. There are a number of empirical studies, which have been carried out to examine the relationship between financial liberalization and financial instability though conclusions are varied.

Of the available studies, Dell'Arricia and Marquez (2006), argues that the liberalisation of the financial sector results in an increase in credit availability as banks relax their screen efforts. This will result in risk projects being funded, which increase the probability of failure and default. In another study, Bezemer et al. (2015) established that entry of risky entrepreneurs due to a decrease in borrowing costs can be another channel through which financial liberalization may result in financial instability. Utilizing impaired loans as a measure of financial liberalization the authors established that countries, which are more liberalized, experienced more financial instability during the 2008 global financial crisis. There are studies, which have established that financial liberalization results in a credit boom. Of these studies, Kaminsky and Schmukler (2003) established that financial liberalization results in an increased inflow of capital, which is then followed by a domestic credit boom. This is consistent with the IMF World Economic Outlook 2011 survey report, which shows that in 19 advanced, and 28 emerging economies financial sector liberalisation resulted in an increase in the inflow of external financial resources, which contributed to a credit boom. In addition, Magud et al. (2012) also established that in 25 emerging economies, huge capital inflow following financial sector liberalisation raised domestic credit.

These findings are consistent with Calderón and Kubota (2012) and Furceri, Guichard, and Rusticelli (2012). There are a series of studies also which have established that financial liberalisation may expose countries to crises. Of these studies Rancière, Tornell and Westerman (2006) established that countries which have financial systems which are liberalised, they have a high probability of experiencing a financial crisis. This will also result in a contraction in output. Studies by Bordo, Barry, Daniela, Maria, Martinez, and Andrew (2001), Eichengreen and Arteta (2000), Barrel, Davis, Karim and Liadze (2010), and Rodrik (2005), amongst many, also show a strong association between financial liberalization and the beginning of a financial crisis. Tornell, Westermann and Martinez (2003) also highlight that financial liberalization does come with benefits. The authors indicate that in countries with developed financial markets, financial liberalization has contributed towards growth, but as well as to higher chances of instability. Tornell et al. (2003) also suggest that liberalization results in faster growth as it results in lessened financial constraints, but this happens when agents take on credit risk, which in turn makes the economy fragile and exposed to a crisis. Financial instability is measured by impaired loan Ratio (ILR) which is a share of loans due by 90 days in gross loans. 


\section{Data and Research Methodology}

Model Specification: The study is based on the De Meza and Webb (1987) model discussed earlier which proposes that there is a link between financial liberalization and financial instability. In the model, it is assumed that entrepreneurs borrow money from banks to start projects. As a country liberalise its financial sector, there will be more credit available, which increases the degree of over-borrowing. In addition, due to excessive credit availability, this may attract risk entrepreneurs who are likely to default. Thus, as many entrepreneurs' default, this amounts to financial sector instability. Based on the model and Bezemer et al. (2015), the following equation is proposed:

$$
I L R_{i t}=f(\text { Fin } \operatorname{Re} \text { form, } d \text { TxFin } \operatorname{Re} \text { form }, X)
$$

Where $I L R$ is the impaired loans ratio, FinLibit-p is financial liberalization $d T$ represents a dummy variable measuring the financial crisis. The study took into account the 2008 global financial crisis $\left(d T_{\text {global }}\right)$ which assumes values of 1 and 0 after and before the respective crisis. $X$ represents a number of control variables such as Private Credit, GDP, Government consumption and Inflation. $T$ represents time and $i$ represent the country. Equation 1 was adopted taking into account other important variables in the SADC countries. Thus the following empirical model was utilised:

$$
\begin{aligned}
& I_{L R}=a_{0}+\beta_{1}{\text { Fin Re } \text { form }_{i t-p}}+\beta_{2}\left(d T_{\text {global }} x \text { Fin Re } \text { form }_{i t-p}\right)+\beta_{3} P C_{i t}+\beta_{4} \text { GDP }_{i t}+ \\
& \beta_{5} \text { GovCons }_{t}+\beta_{6} \text { Inflation }_{i t}+u_{i t}
\end{aligned}
$$

The extent to which financial liberalization may influence the domestic banking sector is not instantaneous (Bezemer, et al. 2015). To account for this, Equation 2 was estimated including a lag of the dependent variable.

$$
\begin{aligned}
& I L R_{i t}=a_{0}+a_{1} I L R_{-1}+a_{2} \text { Fin Re form } \text { for }-p_{3}+a_{3}\left(d T_{\text {global }} x \text { FinRe form } \text { fit }_{p}\right)+a_{4} P C_{i t}+a_{5} G D P_{i t}+{ }_{3} \\
& a_{6} \text { Gov Cons }_{t}+a_{7} \text { Inflation }_{i t}+u_{i t}
\end{aligned}
$$

Definition of Variables and Expectation Apriori: Financial instability is measured by an impaired loan which is a ratio of loans which are 90 days overdue to gross loans. This is consistent with Bezemer, et al. (2015). Financial liberalization is measured by financial reform Index of Abiad, Detragiache and Tressel (2010). The index is based on seven dimensions ranging between 0 and 21. The literature review section indicated how financial liberalization might act as a catalyst for financial instability after a shock. Thus the 2008 financial crisis will be treated as an external shock. In this case, the 2008 Global financial crisis interacted with the financial liberalization variable. For control variables, financial development is measured by Private credit as a percentage of gross domestic products (GDP). A negative relationship between financial instability and financial sector development is expected. Credit to the private sector is expected to have a negative relationship with financial instability. GDP per capita is used to measure economic growth. Inflation is measured by the GDP deflator. Government consumption represents the role of the government in the domestic economy.

Data Sources: Data were collected for four countries, thus South Africa, Mozambique, Tanzania and Madagascar. The choice for the countries to be included in the study was based on the availability of data. Data on financial liberalisation is up to 2012. This has resulted in the study period being confined to the period mentioned above. The data for impaired loan ratio was obtained from the DFID project database. The remaining variables namely private credit, per capita GDP, inflation and government consumption were obtained from the World Development Bank indicators in annual form.

Estimation Technique: The study utilised panel data given the nature of the variables utilised in the study. Panel data analysis is a combination of time series and cross-sectional data. Generally, the two approaches to panel data analysis are the random effects model and the fixed effects model. The Random effects model treats the constants for each section as a random parameter. The advantages of the of the random effects model are that the model has fewer parameters as compared to the fixed effects model. It also allows the use 
of dummies. However, there are a number of challenges with the model. Firstly, there is needed to make assumptions pertaining to the distribution of the random component. Secondly, in the event that the unobserved group-specific effects are correlated with the explanatory variables, the estimates will be biased and inconsistent. On the other hand, concerning the fixed effects model, the constant is treated as groupspecific. The model allows for the different constants for each group. The model is also known as the least square dummy variable (LSDV) estimator. In this regard, the model includes a dummy variable for each group. The model can be written as follows:

$Y_{i t}=a_{i}+\beta_{1} X_{1 i t}+\beta_{2} X_{2 i t}+\ldots \ldots \ldots . .+\beta_{k} X_{k i t}+u_{i t}$

This can be written as:

$Y=D \alpha+X \beta^{\prime}+u$

The dummy variable allows one to take different group-specific estimates for each of the constants for each different section.

The Hausman Test: The Hausman Specification Test was utilised to choose between the fixed effects and the random effects model. The test assumes that there are two estimators, $\beta_{0}$ and $\beta_{1}$ of the parameter vector $\beta$. The test thus tests the two parameters whether the random effects are consistent and efficient under the null hypothesis, against the alternative that the fixed effects are consistent.

Diagnostic Test: The study also used the residual cross-section dependence test as a diagnostic test. According to Pesaran (2004) this test is a simple test of error cross-section dependence which can apply to many panel data models with a Large $\mathrm{N}$, but small $\mathrm{T}$. Cross-sectional dependency in the panel, data can be tested by three tests. These are the Pesaran CD, Bruesch-Pegan and the corrected LM tests.

\section{Presentation of Empirical Results}

Correlation Matrix: Table 1 reports the relationship between impaired loans, financial reforms and the control variables namely inflation, domestic credit in the private sector, government expenditure and GDP. As shown in Table 1, the correlation between impaired loans, credit to the private sector and government expenditure is positive and also significant.

Table 1: Correlation Matrix

\begin{tabular}{|c|c|c|c|c|c|c|}
\hline & $\begin{array}{l}\text { FINANCIAL_REF } \\
\text { ORMS }\end{array}$ & $\begin{array}{l}\text { LIMPAIRE } \\
\text { D_LOANS }\end{array}$ & LDCP & $\begin{array}{l}\text { LGOVERNME } \\
\text { NT_EXP }\end{array}$ & $\begin{array}{l}\text { LINFLATI } \\
\text { ON }\end{array}$ & $\begin{array}{l}\text { GDP_GROW } \\
\text { TH }\end{array}$ \\
\hline FINANCIAL_REFORMS & 1 & & & & & \\
\hline LIMPAIRED_LOANS & $0.203^{*}$ & 1 & & & & \\
\hline P-value & $(0.309)$ & $-\ldots--$ & & & & \\
\hline LDCP & $0.750^{*}$ & $0.055^{* *}$ & 1 & & & \\
\hline P-value & $(0.000)$ & $(0.781)$ & --.-- & & & \\
\hline LGOVERNMENT_EXP & $0.365^{*}$ & $0.023^{* *}$ & $0.527^{*}$ & 1 & & \\
\hline $\begin{array}{l}\text { P-value } \\
\text { LINFLATION }\end{array}$ & $\begin{array}{l}(0.061) \\
-0.018^{* *}\end{array}$ & $\begin{array}{l}(0.234) \\
0.046^{* *}\end{array}$ & $\begin{array}{l}(0.004) \\
-0.121^{*}\end{array}$ & $-0.162^{*}$ & 1 & \\
\hline P-value & (0.929) & $(0.817)$ & $(0.544)$ & $(0.418)$ & ---- & \\
\hline GDP_GROWTH & $-0.241^{*}$ & $0.006^{* *}$ & $-0.231^{*}$ & $0.280^{*}$ & $-0.246^{*}$ & 1 \\
\hline P-value & $(0.224)$ & $(0.972)$ & $(0.246)$ & $(0.155)$ & $(0.215)$ & ----- \\
\hline
\end{tabular}

*** $0.01 \mathrm{p}<$ level; ${ }^{* *} \mathrm{p}<0.05$ level; $* \mathrm{p}<0.1$ level

Source: Author (Computed with E views 8)

Choosing the Correct Model: The Hausman test was estimated so as to choose the appropriate model and the results are presented in table 2. 
Table 2: Hausman Test and F-Test

\begin{tabular}{|c|c|c|c|}
\hline Test & Test Statistic & Critical value & Conclusion \\
\hline $\begin{array}{l}\text { Redundant Fixed Effects Test } \\
\mathrm{H}_{0} \text { : Cross-sections are homogenous }\end{array}$ & \multirow[t]{2}{*}{$\mathrm{F}=5.226$} & $\begin{array}{l}\text { P-value }= \\
0.000897\end{array}$ & \multirow{2}{*}{$\begin{array}{l}\text { We reject } \mathrm{H}_{0} \text { and conclude that } \\
\text { the Fixed effects model should be } \\
\text { used to account for country- } \\
\text { specific features. }\end{array}$} \\
\hline $\begin{array}{l}\mathrm{H}_{1}: \quad \text { Cross-sections } \quad \text { are } \\
\text { heterogeneous }\end{array}$ & & & \\
\hline $\begin{array}{l}\text { Random effects vs Fixed effects } \\
H_{0:} \mu_{1}=\mu_{2}=\ldots=\mu_{\mathrm{N}-1}=0 \\
\mathrm{H}_{\mathrm{A}}: \text { Not all equal to } 0 \text {. }\end{array}$ & $\begin{array}{l}\text { Chi- } \\
\text { Square=33.337 }\end{array}$ & $P$-value $=0.00$ & $\begin{array}{l}\text { We reject } \mathrm{H}_{0} \text {. This means the } \\
\text { fixed effects model is the best } \\
\text { model that allows heterogeneity. }\end{array}$ \\
\hline
\end{tabular}

Source: Author (Hausman test and F- test computed with E views 8)

Regressions on the Impact of Financial Liberalization on ILR: Table 3 shows the results of regressions with the impact of financial liberalization on impaired loans ratio. The empirical results indicate that there is a positive relationship between financial instability and financial liberalization. A $1 \%$ increase in financial liberalization contributed 0.0745 percent increase in financial instability these results are in line with the apriori expectation and are also in line with the study of Dell'Arricia and Marquez (2006). The authors argue that financial liberalisation results in an increase in financial resources. This does also result in funding of risk projects which may default in payment resulting in a financial crisis. The probability value for the test is less than $1 \%$ level of significance, indicating that the random effect panel data technique is not suitable for this study and a fixed effect was chosen. In Equation two, the financial reform dummy variable and domestic credit to the private sector were introduced.

The introduced dummy variables captured the global financial crisis. Financial reform without the dummy variable was found to be positive and significant. When the financial reform interacted with the dummy, the relationship between financial instability and financial liberalization was positive though insignificant. This suggests that a $1 \%$ increase in financial reforms resulted in 0.238 percent increase in financial instability. This result again is consistent with Dell'Arricia and Marquez (2006), Lorenzoni (2008), Magud, et al. (2012), Calderón and Kubota (2012), Bezemer, et al. (2015). The authors highlight that during the global financial crisis, financial liberalization resulted in an increase in competition by banks so as to maintain their profitability. This exposed the banks to risk entrepreneurs who defaulted in payment of their obligations and hence banks failures.

Table 3: Regressions with the Impact of Financial Liberalization on ILR

\begin{tabular}{llll}
\hline \multirow{2}{*}{ Variables } & Equation 1 & Equation 2 & Equation 3 \\
\cline { 2 - 4 } FINANCIAL_REFORMS(-4) & FE & FE & FE \\
FINANCIAL_REFORMS(-4)*DT & 0.0745 & 0.638 & 0.616 \\
& $(0.54)$ & $(0.0006)$ & $(0.001)$ \\
LDCP & & 0.238 & 0.262 \\
& & $(0.2291)$ & $(0.195)$ \\
LGOVERNMENT_EXP & & $-0.870^{*}$ & $-0.740^{*}$ \\
& & $(0.001)$ & $(0.001)$ \\
LINFLATION & & -0.915 \\
& & & $(0.035)$ \\
GDP_GROWTH & & & $-0.036^{* *}$ \\
& & & $(0.889)$ \\
CONSTANT & & & 0.004 \\
Years effects & 0.463 & -6.994 & $(0.896)$ \\
R-squared & $(0.811)$ & $(0.0016)$ & -4.601 \\
Adjusted R-squared & Yes & Yes & $(0.037)$ \\
\hline
\end{tabular}

Note: ${ }^{* * *} \mathrm{p}<0.01$ level; ${ }^{* *} \mathrm{p}<0.05$ level; ${ }^{*} \mathrm{p}<0.1$ level

Source: Author (Computed with E views 8) 
On the other hand, the results show that for all the control variables, private credit, government expenditure and inflation they are all negatively related to financial instability. With regards to private credit which is the measure of financial development is negatively related to the financial crisis. This result is consistent with the findings of Abiad et al. (2010), Balmaceda, Fischer and Ramirez (2013) and Bezemer et al. (2015) who concluded that financial development increases financial openness which creates competitiveness, slowing down financial instability. It is essential to note that financial reform index including the Financial Reforms (4)*DT capturing the dummy which captures the global financial crisis in all the three equations has a positive relationship with impaired loans. This implies that banks in more financially liberalized selected SADC region countries prove to be financially unstable when there is a financial crisis. This is consistent with Bezemer (2015). In addition, the findings of Rancière, Tornell and Westerman (2006), are in line with these results.

Regressions with Lagged Dependent Variable: In table 4 the dependent variable ILR is lagged. When the dependent variable has been lagged, the coefficients of ILR are significantly positive in all the three equations. This implies that there is partiality amongst the coefficients. The coefficient of ILR also increases. Bezemer, et al. (2015) indicates that a higher ILR ratio is an indication of financial instability. When the dependent variable is lagged, Equation one shows a negative relationship between financial reform index and financial instability and this relationship is also statistically insignificant. In Equation two and three the relationship changes to positive, but continues to be statically insignificant. On the other hand, financial reform index with a dummy variable has a positive relationship with financial instability and this relationship remains the same in all three equations. This is consistent with the study of Bezemer, et al. (2015). The authors highlight that liberalized economies are prone to the financial crisis which may also affect their growth prospects. Domestic credit to private is added into Equations two and three. In both the specifications, domestic credit to the public has a negative relationship with financial instability. The estimations show that an increase in credit in the private sector contributes to the decline of financial instability. These results are expected as according to Abaid, et al. (2010) who observed that more efficient credit allocation contributes to financial stability.

Table 4: Regression with Lagged Dependent Variable (ILR)

\begin{tabular}{llll}
\hline & Equation 1 & Equation 2 & Equation 3 \\
\hline Variables & FE & FE & FE \\
\hline IMPAIRED_LOANS(1) & 0.836 & 0.696 & 0.424 \\
& $(0.0003)$ & $(0.01)$ & $(0.211)$ \\
FINANCIAL_REFORMS(-4) & -0.056 & 1.122 & 2.000 \\
& $(0.943)$ & $(0.453)$ & $(0.198)$ \\
FINANCIAL_REFORMS(-4)*DT & 0.113 & 0.044 & 1.226 \\
& $(0.941)$ & $(0.977)$ & $-2.467)$ \\
LDCP & & -1.572 & $(0.132)$ \\
& & $(0.351)$ & -0.199 \\
GDP_GROWTH & & $(0.498)$ \\
& & & -4.859 \\
LGOVERNMENT_EXP & & & $(0.187)$ \\
& & & -2.823 \\
LINFLATION & & -10.975 & $(0.212)$ \\
& & $(0.533)$ & -4.623 \\
CONSTANT & 2.046 & & $(0.793)$ \\
& $(0.849)$ & Yes & Yes \\
Time Effects & & 30 & 30 \\
Observations & Yes & 0.69 & 0.75 \\
R-Square & 30 & & \\
\hline
\end{tabular}

Note: ${ }^{* * *} \mathrm{p}<0.01$ level; ${ }^{* *} \mathrm{p}<0.05$ level; ${ }^{*} \mathrm{p}<0.1$ level

Source: Author (Computed with E views 8) 
Residual Cross-Section Dependence Test: Diagnostic tests were conducted on the model. The results are presented in table 5.

Table 5: Residual Cross-Section Dependence Test

\begin{tabular}{|c|c|c|c|}
\hline Test & Test Statistic & $\begin{array}{l}\text { Critical } \\
\text { value }\end{array}$ & Conclusion \\
\hline $\begin{array}{l}\text { Breusch-Pagan LM } \\
\mathrm{H}_{0}: \text { There is no cross-section } \\
\text { dependence in the residuals. } \\
\mathrm{H}_{1}: \text { There is no cross-section } \\
\text { dependence in the residuals. }\end{array}$ & 16.179 & $\begin{array}{l}\text { P-value }= \\
0.0100897\end{array}$ & $\begin{array}{l}\text { We accept } \mathrm{H}_{0} \text { and conclude that } \\
\text { the model has no cross-section } \\
\text { dependence in residuals. }\end{array}$ \\
\hline $\begin{array}{l}\text { Pesaran scaled LM } \\
\mathrm{H}_{0}: \text { There is no cross-section } \\
\text { dependence in the residuals. } \\
\mathrm{H}_{1}: \text { There is no cross-section } \\
\text { dependence in the residuals. }\end{array}$ & 1.784 & $P$-value $=0.00$ & $\begin{array}{l}\text { We accept } \mathrm{H}_{0} \text { and conclude that } \\
\text { the model has no cross-section } \\
\text { dependence in residuals. }\end{array}$ \\
\hline $\begin{array}{l}\text { Pesaran CD Test } \\
\mathrm{H}_{0}: \text { There is no cross-section } \\
\text { dependence in the residuals. } \\
\mathrm{H}_{1}: \text { There is no cross-section } \\
\text { dependence in the residuals. }\end{array}$ & -0.0068 & P-value $=0.99$ & $\begin{array}{l}\text { We reject } \mathrm{H}_{0} \text { and conclude that } \\
\text { the model has no cross-section } \\
\text { dependence in residuals. }\end{array}$ \\
\hline
\end{tabular}

The Residual Cross-Section Dependence Tests were run. In table 5 both LM test results showed a probability of 0.0128 and 0.0745 , respectively. This indicates that, there is no correlation between the residual values in the model, and the null hypothesis is therefore accepted. The results of the Pesaran CD test show a probability of 0.99 . This indicates that, there is a correlation between the residual values in the model and the null hypothesis can be rejected.

\section{Summary and Conclusion}

The main objective of the study was to empirically examine the extent to which liberalization of the financial system can contribute toward financial instability in the selected SADC countries. Findings indicated that, financial liberalization may be another source of financial instability in the region. The results also established that there is a negative relationship between financial sector development and instability. This suggests that financial sector development plays a very important role in reducing financial instability over time, and not just instantly. This suggests that policymakers should focus on reforms that give due share to the regulations rather than just simply liberalizing the financial sector.

\section{References}

Abiad, A., Detragiache, E. \& Tressel, T. (2010). A New Database of Financial Reforms. IMF Staff Papers, 57(2), 281-301.

Balmaceda, F., Fischer, R. \& Ramirez, F. (2013). Financial liberalization, market structure and credit penetration. Journal of Financial Intermediation, 23(1), 47-75.

Barrell, R., Davis, E. P., Karim, D. \& Liadze, I. (2010). Bank regulation, property prices and early warning systems for banking crises in OECD countries, Journal of Banking and Finance, 34, 2455-64.

Bordo, M., Barry, E., Daniela, K., Maria, S., Martinez, P. \& Andrew, R. (2001). Is the Crisis Problem Growing More Severe? Economic Policy, 16(32), 51-82.

Brooks, C. (2008). Introduction to Econometrics. Cambridge Press.

Bezemer, D., Bumann, S. \& Lensink, R. (2015). Financial Liberalization and Financial Instability. Faculty of Economics and Business: University of Groningen.

Bumann, S. \& Lensink, R. (2016). Capital account liberalization and income inequality. Journal of International Money and Finance, 61, 143-162.

Calderón, C. \& Kubota, M. (2012). Gross inflows gone wild: gross capital inflows, credit booms and crises, Policy Research Working Paper no. 6270, The World Bank. 
De Meza, D. \& Webb, D. C. (1987). Too much investment: A problem of asymmetric information, Quarterly Journal of Economics, 102(2), 281-292.

Dell'Ariccia, G. \& Marquez, R. (2006). Lending booms and lending standards, Journal of Finance, 61(5), 25112546.

Demirgüç-Kunt, A. \& Levine, R. (2008). Finance, Financial Sector Policies, and Long-Run Growth. M. Spence Growth Commission Background Paper, No 11, World Bank, Washington, DC.

Eichengreen, B. \& Arteta, C. (2000). Banking crises in emerging markets: presumptions and evidence. Centre for International and Development Economics, WP C00-115.

Enowbi, B. M. \& Mlambo, K. (2012). Financial liberalization, Banking Crises and Economic Growth in African Countries, MPRA Paper 41524, University Library of Munich, Germany.

Furceri, D., Guichard, S. \& Rusticelli, E. (2012). The effect of episodes of large capital inflows on domestic credit, North American Journal of Economics and Finance, 23(3), 325-344.

Ikhide, S. I. \& Alawode, A. (2002). On the sequencing of financial liberalization in Nigeria. South African Journal of Economics, 70(1), 95-127, 03.

Kaminsky, G. L. \& Schmukler, S. L. (2003). Short-run pain, long-run gain: The effects of financial liberalization, IMF Working Paper no. 03/34, International Monetary Fund.

Lorenzoni, G. (2008). Inefficient credit booms, Review of Economic Studies, 75(3), 809-833.

Magud, N. E., Reinhart, C. M. \& Vesperoni, E. R. (2012). Capital inflows, exchange rate flexibility, and credit booms. IMF Working Paper no. 41, International Monetary Fund.

McKinnon, R. I. (1973). Money and Capital in Economic Development. Washington DC: Brookings Institution.

Patnaik, P. (2011). The Meaning of Financial Liberalisation. Monthly Review Press 4 June 2011.

Pesaran, M. (2004). General Diagnostic Tests for Cross Section Dependence in Panels, Cambridge Working Papers in Economics, No. 435, University of Cambridge, and CESifo Working Paper Series No, 1229.

Rancière, R., Tornell, A. \& Westermann, F. (2006). Decomposing the effects of financial liberalization: Crises vs. growth, Journal of Banking \& Finance, 30(12), 3331-3348.

Rodrik, D. (2005). Growth Strategies, Handbook of Economic Growth, in: Philippe Aghion \& Steven Durlauf (ed.), Handbook of Economic Growth, edition, 1(14), 967-1014.

Shaw, E. S. (1973). Financial Deepening in Economic Development, Oxford University Press, New York.

Tornell, A. \& Westermann, F. (2003). Credit Market Imperfections in Middle-Income Countries, NBER WP, 9737. 